\title{
Mitochondrial and Y chromosome genetic diversity in the Portuguese Lidia bovine breed
}

\author{
Pedro Bettencourt Cardoso Correia ${ }^{1^{\star}}$, Erica Elias Baron ${ }^{1}$, Joaquim Fernando Moreira da Silva ${ }^{1}$, \\ Óscar Cortés Gardyn²
}

\footnotetext{
${ }^{1}$ Universidade dos Açores, Departamento de Ciências Agrárias, Grupo de Reprodução Animal, Angra do Heroísmo, Portugal.

${ }^{2}$ Universidad Complutense de Madrid, Facultad de Veterinária, Laboratorio de Genética, Madrid, Comunidad de Madrid, Spain.
}

\begin{abstract}
A total of 80 samples were collected to analyze the mitochondrial DNA (mtDNA) and Y chromosome genetic diversity of two main Portuguese Lidia bovine populations and clarify their genetic relationships with Spanish Lidia lineages. A 521-bp D-loop fragment was sequenced in 40 animals belonging to four herds (three Brava dos Açores and one Casta Portuguesa) and the same number of samples were collected with equal distribution from males in order to genotype six microsatellites, one single nucleotide polymorphism, and one indel. The mtDNA diversity recorded was similar to that observed in Lidia cattle. Haplotype T3 was the most common (62.5\%), followed by the African T1 haplotype (25\%); very low frequencies were recorded for haplotypes T2 $(2.5 \%)$ and the Lidia haplogroup L4 (10\%). The results support the existence of two major ancestral lines for the Lidia breed: European and African, similar to other Mediterranean breeds. However, the genetic diversity in the Y chromosome was lower in Portuguese Lidia lineages than in Lidia cattle and other bovine breeds (haplotype diversity $=0.09$ ). The two major paternal haplogroups, Y1 and Y2, were present with $2.5 \%$ and $97.5 \%$, respectively. Our results evidenced a similar paternal and maternal genetic pattern to those found in Spanish Lidia lineages and a high reproductive isolation.
\end{abstract}

Key Words: Lidia cattle, mitochondrial DNA, Portuguese lineages, Y chromosome

\section{Introduction}

The Lidia bovine breed is mainly distributed in the west and southwest of Spain, Portugal, south of France, and in South America. The Lidia bovine breeding and selection objective, which is based on aggressiveness, is unique and has led to its reproductive isolation from other cattle breeds, in which this behavioral characteristic is discouraged (Silva et al., 2006; UCTL, 2011). Nevertheless, traditional events have created a demand for different types of behavior and this need has favored the subdivision of the Lidia bovine breed into lineages (called "encastes") (BOE, 2001), with limited gene flow among them. Portugal has a unique Lidia cattle lineage, called Casta Portuguesa, which is considered one of the most important Portuguese Lidia

Received: April 15, 2016

Accepted: October 19, 2016

*Corresponding author: pedro.bc.correia@uac.pt

http://dx.doi.org/10.1590/S1806-92902017000200003

How to cite: Correia, P. B. C.; Baron, E. E.; Moreira da Silva, J. F. and Cortés, O. G. 2017. Mitochondrial and Y chromosome genetic diversity in the Portuguese Lidia bovine breed. Revista Brasileira de Zootecnia 46(2):99-104.

Copyright (C) 2017 Sociedade Brasileira de Zootecnia. This is an Open Access article distributed under the terms of the Creative Commons Attribution License (http://creativecommons.org/licenses/by/4.0/), which permits unrestricted use, distribution, and reproduction in any medium, provided the original work is properly cited. breed resources (Lucas, 2006; Correia et al., 2014; Mateus and Russo-Almeida, 2014).

The arrival of bovines in the Azores began in the 15th century with the colonization of the islands, primarily by the Portuguese. Also, at the beginning of the 20th century, different Lidia lineages, that also included Casta Portuguesa, began to be selected on Terceira Island (Azores) for a cultural event called "Tourada à Corda" (Bruges, 1915; Silva, 2011; Correia et al., 2015). This cattle population located on Terceira Island is recognized as Toiro da Terra or Brava dos Açores (Department of Azorean Agriculture and Forestry, 2010).

Previous analysis with autosomal microsatellites showed a Lidia lineage crossbreeding origin from Brava dos Açores breed and higher genetic diversity than the Casta Portuguesa lineage (Correia et al., 2014). Presently, the "Tourada à Corda" event is important for the local economy, as well as for the Azorean social and cultural heritage, and also ensures the viability of Brava dos Açores breed. However, in spite of the genetic, economic, and social importance of Casta Portuguesa and Brava dos Açores breeds, their maternal and paternal genetic influences have not yet been analyzed. The objective of this study is to analyze the mitochondrial DNA (mtDNA) and $\mathrm{Y}$ chromosome genetic diversity of Brava dos Açores and 
Casta Portuguesa and evaluate the paternal and maternal relationships between Portuguese and Spanish Lidia lineages.

\section{Material and Methods}

A total of 80 peripheral blood samples were collected: Irmãos Dias (ID; $\mathrm{n}=20$ ), belonging to Casta Portuguesa; and three herds belonging to Brava dos Açores - José Albino Fernandes (JAF; $n=20$ ), Rego Botelho (RB; $n=20$ ), and Eliseu Gomes (EG; $n=20)$. Samples were collected from unrelated individuals registered in herdbooks (whenever available). Biological samples were collected by qualified veterinarians during their routine practice, according to the framework of official programs. We extracted DNA by standard methods (Sambrook et al., 1989). A 521-bp fragment of the mtDNA D-loop was sequenced following the procedure described in Cortés et al. (2008). The primer sequences and annealing temperature of the six Y chromosome microsatellites (DYZ1, BYM1, BM861, UMN0307, INRA189, and UMN0103), the single nucleotide polymorphism (UTY19), and the indel (ZFY10) were described in Cortés et al. (2011) (Table 1). To study the genetic relationships among Portuguese bovine populations and Spanish Lidia breed lineages, mtDNA sequences and $\mathrm{Y}$ chromosome genotypes belonging to 30 previously analyzed Spanish Lidia lineages were added to the analysis (Cortés et al., 2008; 2011).

The mtDNA sequence alignment was performed using free software available at http://bioinfo.hku.hk/EMBOSS/ (the European Molecular Biology Open Software Suite). The mean number of pairwise differences (MNPD) and nucleotide diversity were obtained using MEGA software version 2.1 (Kumar et al., 2001). The $\mathrm{F}_{\mathrm{ST}}$ genetic distances was carried out using ARLEQUIN package version 3.11 (Excoffier et al., 2005). Reduced median networks were generated using software NETWORK version 4.6.1.3 (Bandelt et al., 1999).

\section{Results}

The Portuguese Lidia populations showed MNPD values ranging from 3.7 in Rego Botelho to 6.5 in Eliseu Gomes (Table 1). The nucleotide diversity ranged from $0.5 \%$ to $0.8 \%$ (Table 1 ).

The 40 DNA mitochondrial sequences revealed 20 haplotypes defined by 48 polymorphisms, 45 transitions, and three transversions (Table 2). The most common haplogroup was T3 in Casta Portuguesa (80\%) and Brava dos Açores $(57 \%)$ (Table 1). However, there were notable differences in frequency of haplogroup T3 among Brava dos Açores herds (José Albino Fernandes, 50\%; Rego Botelho, 40\%; and Eliseu Gomes and Irmãos Dias, 80\%). The haplogroup T1 was identified in both Portuguese bovine populations (Brava dos Açores, 30\%; Casta Portuguesa, 10\%), ranging from $10 \%$ to $30 \%$ in Brava dos Açores herds. Finally, haplogroup T2 was only found in Casta Portuguesa (10\%) and L4 in Brava dos Açores (José Albino Fernandes, 20\%; Rego Botelho, 20\%) (Figure 1).

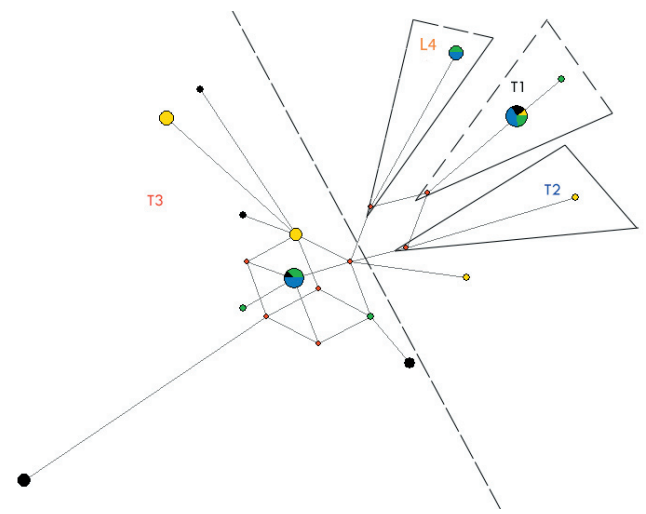

Dashed line identifies T3 from other haplogroups marked with triangles.

Circle size is proportional to sequence frequency.

Line colors: green $=$ José Albino Fernandes; blue $=$ Rego Botelho; black $=$ Eliseu Gomes; yellow = Irmãos Dias.

Figure 1 - Reduced median-joining network constructed from 20 maternal haplotypes from Portuguese lineages (Brava dos Açores and Casta Portuguesa), belonging to main maternal haplogroups previously published (T1, T2, and T3) and L4.

Table 1 - Mean number of pairwise differences (MNPD), nucleotide diversity, and frequencies of the main maternal haplotypes for each herd

\begin{tabular}{|c|c|c|c|c|c|c|c|}
\hline & \multirow{2}{*}{ Herd } & \multirow{2}{*}{ MNPD } & \multirow{2}{*}{$\begin{array}{c}\text { Nucleotide } \\
\text { diversity }\end{array}$} & \multicolumn{4}{|c|}{ Haplotypes (\%) } \\
\hline & & & & $\mathrm{T} 1$ & $\mathrm{~T} 2$ & $\mathrm{~T} 3$ & L4 \\
\hline \multirow{3}{*}{ Brava dos Açores } & José Albino Fernandes & $4.2 \pm 2.3$ & $0.005 \pm 0.003$ & 30 & & 50 & 20 \\
\hline & Rego Botelho & $3.7 \pm 2.1$ & $0.005 \pm 0.003$ & 40 & & 40 & 20 \\
\hline & Total & 4.8 & 0.006 & 30 & & 56.7 & 13.3 \\
\hline Casta Portuguesa & Irmãos Dias & $3.9 \pm 2.2$ & $0.005 \pm 0.003$ & 10 & 10 & 80 & \\
\hline
\end{tabular}


Among Portuguese Lidia populations, Casta Portuguesa showed the highest $\mathrm{F}_{\mathrm{ST}}$ genetic distances, ranging from $18 \%$ to $27 \%$ (Table 3 ). The average $\mathrm{F}_{\mathrm{ST}}$ genetic distances among Brava dos Açores, Casta Portuguesa, and the Iberian Peninsula Lidia lineages ranged from 3.2\% for Braganza to $20.3 \%$ for Pedrajas (Table 2). In addition, Portuguese bovine populations showed average $\mathrm{F}_{\mathrm{ST}}$ genetic distances higher than 10\% (José Albino Fernandes, 10.1\%;

Table 2 - Average $\mathrm{F}_{\mathrm{ST}}$ value from maternal DNA for each lineage with respect to the others

\begin{tabular}{|c|c|}
\hline Herd & $\mathrm{F}_{\mathrm{ST}}$ distance $\%$ \\
\hline Pedrajas & 20.3 \\
\hline Maria Montalvo & 15.6 \\
\hline Rego Botelho & 14.7 \\
\hline Miura & 14.5 \\
\hline Eliseu Gomes & 14.2 \\
\hline Atanásio Fernández & 13.5 \\
\hline Irmãos Dias & 13.1 \\
\hline Antonio Pérez & 12.5 \\
\hline Concha y Sierra & 10.5 \\
\hline Baltasar Ibán & 10.3 \\
\hline Vega Villar & 10.1 \\
\hline José Albino Fernandes & 10.1 \\
\hline Félix Gómez & 9.7 \\
\hline Marqués de Albaserrada & 9.1 \\
\hline Urcola & 8.7 \\
\hline Pablo Romero & 8.3 \\
\hline Manuel Arranz & 8.1 \\
\hline Anastasio Martin & 7.8 \\
\hline Conde de la Corte & 7.6 \\
\hline Hidalgo Barquero & 7.6 \\
\hline Murube & 7.3 \\
\hline Cuadri & 7.3 \\
\hline Arauz de Roblez & 7.2 \\
\hline Santa Coloma & 6.9 \\
\hline Juan Pedro Domecq & 6.4 \\
\hline Veragua & 6.1 \\
\hline Contreras & 6.1 \\
\hline Gamero Cívico & 6.1 \\
\hline Marqués de Villamarta & 6 \\
\hline Carlos Núñez & 5.9 \\
\hline Saltillo & 4.4 \\
\hline Diego Garrido & 4.1 \\
\hline Jose Marzal & 4 \\
\hline Braganza & 3.2 \\
\hline
\end{tabular}

Rego Botelho, 14.7\%; Eliseu Gomes, 14.2\%, and Irmãos Dias, 13.1\%).

The six Y chromosome microsatellites revealed a total of three haplotypes. The haplotype $\mathrm{H} 1$ was the most frequently detected in both Portuguese bovine populations analyzed (95\%) (Table 3). The haplotypes H3 and H5 were identified in Brava dos Açores Eliseu Gomes and Rego Botelho herds, respectively (EG - H3, 10\%; RB - H5, 10\%). According to the two major paternal haplogroups identified in European bovine populations, $\mathrm{H} 1$ and $\mathrm{H} 5$ haplotypes belong to haplogroup Y2 (total frequency of 97.5\%) and H3 to haplogroup Y1 (2.5\%) (Table 3).

The Portuguese bovine populations evidenced low average $\mathrm{F}_{\mathrm{ST}}$ genetic distances as a consequence of their high $\mathrm{H} 1$ haplotype frequency, which is the most frequent in Spanish Lidia lineages (Table 4).

The relationships among $\mathrm{Y}$ chromosome haplotypes were shown in the Median-Joining network (Figure 2). The haplotypes belonging to haplogroups Y1 and Y2 were clearly separated into two clusters.

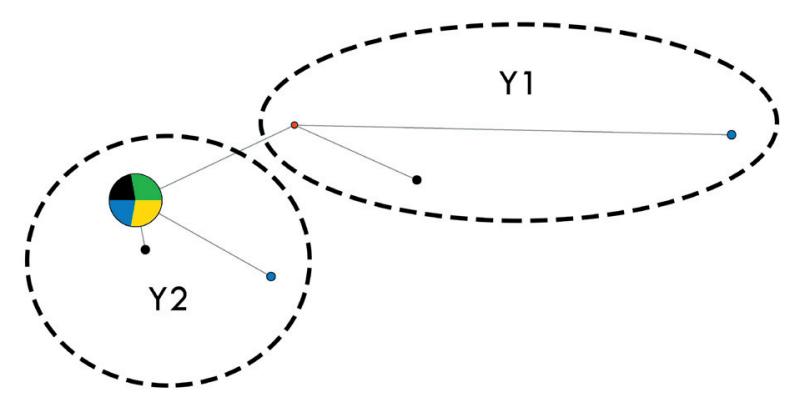

The sizes of the circles are proportional to their frequencies and their classification into the two aim European haplogroups (Y1 and Y2).

Colors: green $=$ José Albino Fernandes; blue $=$ Rego Botelho; black = Eliseu Gomes yellow $=$ Irmãos Dias.

Figure 2 - Network representation of the three haplotypes identified in the Portuguese Lidia lineages (Brava dos Açores and Casta Portuguesa).

Table 3 - Number of samples analyzed $(\mathrm{N})$, percentage of haplotype and haplogroup frequencies, and haplotype diversity (He) for each lineage and for the entire population

\begin{tabular}{|c|c|c|c|c|c|c|c|c|}
\hline & \multirow{2}{*}{ Herd } & \multirow{2}{*}{$\mathrm{N}$} & \multicolumn{3}{|c|}{ Haplotype (\%) } & \multicolumn{2}{|c|}{ Haplogroup (\%) } & \multirow{2}{*}{$\mathrm{He}$} \\
\hline & & & H1 & $\mathrm{H} 3$ & $\mathrm{H} 5$ & Y1 & Y2 & \\
\hline \multirow{4}{*}{ Brava dos Açores } & José Albino Fernandes & 10 & 100 & & & & 100 & 0 \\
\hline & Rego Botelho & 10 & 90 & & 10 & & 100 & 0.2 \\
\hline & Eliseu Gomes & 10 & 90 & 10 & & 10 & 90 & 0.17 \\
\hline & Total & 30 & 93.3 & 3.3 & 3.3 & 3.3 & 96.7 & 0.12 \\
\hline Casta Portuguesa & Irmãos Dias & 10 & 100 & & & & 100 & 0 \\
\hline \multicolumn{2}{|c|}{ Portuguese Lidia populations } & 40 & 95 & 2.5 & 2.5 & 2.5 & 97.5 & 0.09 \\
\hline
\end{tabular}


Table 4 - Average $\mathrm{F}_{\mathrm{ST}}$ value from $\mathrm{Y}$ chromosome genetic diversity for each lineage with respect to the others

\begin{tabular}{lc}
\hline Herd & $\mathrm{F}_{\text {ST }}$ distance \% \\
\hline Miura & 96.3 \\
Pablo Romero & 89.4 \\
Marqués de Albaserrada & 82.7 \\
Manuel Arranz & 81.6 \\
Cuadri & 79.8 \\
Vega Villar & 77.5 \\
Saltillo & 72.2 \\
Contreras & 66.5 \\
Atanásio Fernández & 34.6 \\
Gamero Cívico & 25.1 \\
Carlos Núñez & 25.1 \\
Veragua & 24.9 \\
Concha y Sierra & 24.3 \\
Braganza & 24.1 \\
Anastasio Martin & 24.1 \\
Urcola & 24.1 \\
Pedrajas & 24.1 \\
Baltasar Ibán & 24.1 \\
Antonio Pérez & 24.1 \\
Marqués de Villamarta & 24.1 \\
Jose Marzal & 24.1 \\
Hidalgo Barquero & 24.1 \\
Arauz de Roblez & 24.1 \\
Félix Gómez & 24.1 \\
Diego Garrido & 24.0 \\
Conde de la Corte & 23.9 \\
Rego Botelho & 23.7 \\
Eliseu Gomes & 23.5 \\
José Albino Fernandes & 23.4 \\
Irmãos Dias & 23.4 \\
Santa Coloma & 23.0 \\
Murube & 22.4 \\
Maria Montalvo & 21.6 \\
Juan Pedro Domecq & 20.8 \\
\hline & \\
\hline
\end{tabular}

\section{Discussion}

The MNPD in Portuguese Lidia populations were equal to or higher than those observed in Spanish Lidia breed (3.7) (Cortés et al. 2008), European, African, Middle Eastern (4.0), or Anatolian bovine breeds (3.7) (Bradley et al., 1996; Troy et al., 2001; Carvajal-Carmona et al., 2003; Ginja et al., 2010). In addition, the nucleotide diversity was higher in Portuguese Lidia populations than in other European bovine breeds, which ranged from $0.11 \%$ to $0.57 \%$ (Loftus et al., 1994), and was lower than in the Lidia cattle breed ( $0.4 \%$ to $1.1 \%)$ (Cortés et al., 2008).

The haplogroup distribution in Casta Portuguesa and Brava dos Açores has a pattern similar to that in Spanish Lidia lineages or Iberian bovine breeds (Cortés et al., 2008; Ginja et al., 2010). Our results showed clear similarities between Portuguese Lidia populations and Spanish Lidia lineages, in which two major haplogroups were identified (T3 and T1), and supported historical documents that describe the Azorean Lidia cattle as coming from the
Iberian Peninsula (Lucas, 2006; Cortés et al., 2008; UCTL, 2011). However, the African influence in Casta Portuguesa, revealed by $\mathrm{T} 1$ haplotype frequency, is lower than that previously estimated in Spanish Lidia lineages by Cortés et al. (2008).

The remarkably high frequency of the haplogroup L4, previously described by Cortés et al. (2008), in several Spanish Lidia lineages (Pablo Romero, Contreras, Baltasar Iban, and Carlos Núñez lineages), suggests crossbreeding among Lidia lineages and Brava dos Açores populations during their development (Correia et al., 2014).

The presence of the T2 haplogroup identified in Casta Portuguesa has two possible explanations: the well-known genetic relationship between the Concha y Sierra Lidia lineage (in which the T2 haplogroup has been previously observed) and Portuguese Lidia populations (Correia et al., 2014); and the role of populations from the North of Portugal in the development of Casta Portuguesa (Neves, 1992), such as the Marinhoa breed, in which T2 haplogroup has been previously identified (Ginja et al., 2010).

The reproductive isolation of Portuguese and Spanish Lidia lineages could likely explain the higher levels of genetic differentiation among them, evidenced by the high $\mathrm{F}_{\mathrm{ST}}$ values. Furthermore, the low number of animals in both Portuguese bovine populations could have increased the genetic drift effect and, as a consequence, the genetic differentiation from Spanish Lidia lineages.

The higher number of haplotypes in Portuguese bovine populations were grouped in three well-differentiated clusters in a phylogeny network, according the three major haplogroups: T3, T2, and T1. Moreover, the new haplotypes identified in Portuguese bovine populations (L4) were detected in a new cluster, but closer to the $\mathrm{T} 1$ than to the $\mathrm{T} 3$ cluster. This result could support an African origin of the L4 haplogroup.

The three paternal haplotypes evidenced in Portuguese bovine population ( $\mathrm{H} 1, \mathrm{H} 3$, and $\mathrm{H} 5)$ can be attributed to different origins. In Lidia lineages, those haplotypes have been identified in Saltillo and other Lidia lineages that share similar origins (Cortés et al., 2011; UCTL, 2011). The relationship between Saltillo lineage and Portuguese Lidia bovine populations has been previously established (López del Ramo, 2002). Otherwise, H3 was identified in a native bovine breed from Terceira Island, Ramo Grande, which originated from ancient Iberian cattle (Ginja et al., 2010), and the presence of this haplotype in Eliseu Gomes could be evidence of ancestral crossbreeding between both populations (Correia et al., 2014).

The H5 haplogroup, detected in the Domecq Spanish Lidia lineage and Rego Botelho herd, supported the 
introgression previously described in the Rego Botelho herd Domecq lineage during the 1990s (Lucas, 2006). In addition, the $\mathrm{H} 3$ haplogroup identified in the Eliseu Gomes herd could be considered an influence of the Domecq lineage according to a recent study by Pelayo et al. (2015), despite the absence of historical documents to support it (ARCTTC, 2006). While the frequency of $\mathrm{H} 3$ and H5 were low, this finding may suggest a recent introgression of the Spanish Lidia lineages in the Brava dos Açores breed.

The low haplotype diversity found in the analyzed Portuguese bovine populations supports previous analyses conducted on the Lidia bovine breed (Cortés et al., 2011) and other Iberian Peninsula bovine breeds (Ginja et al., 2010). There are several, nonexclusive explanations for the low levels of haplotype diversity in Spanish and Portuguese Lidia bovine populations: low Y chromosome genetic diversity in the ancestral populations of the present bovine breeds; reproductive isolation between lineages and low effective population size (approximately 30 on average); and the traditional practice of using a small number of bulls when trying to fix desirable behavioral traits through inbreeding (Cortés et al., 2011; 2014).

The high frequency of the Y2 haplogroup shown in Portuguese Lidia bovine populations is higher than that previously found in Spanish Lidia lineages (Cortés et al., 2011; Pelayo et al., 2015). Recent studies have suggested that the Y1 haplogroup is more widely distributed than previously assumed as supported by the identification of Y1 exclusively in haplotypes in Spanish cattle breeds (Pelayo et al., 2015). Therefore, the low frequency of the Y1 haplogroup detected in the analyzed Portuguese Lidia bovine populations could be the consequence of the small number of bulls used for reproduction.

\section{Conclusions}

The analyzed Portuguese Lidia populations revealed paternal and maternal genetic patterns similar to those previously described in Spanish Lidia lineages. Two major maternal lineages have been identified (T3 and T1). The Brava dos Açores population evidenced more genetic relationships with Lidia lineages than Casta Portuguesa; however, a high reproductive isolation was observed among Portuguese and Spanish Lidia cattle, which suggests the hypothesis to determine the "lineage" (encaste) as a conservation unity as a consequence of their high reproductive isolation and their genetic differences.

\section{Acknowledgments}

This project was supported by the Ph.D. scholarship (M3.1.2/F/050/2011), Direção Regional do Desenvolvimento Agrário (DRDA) of the Fundo Regional da Ciência (FRC) and also Direção Regional do Desenvolvimento Agrário (DRDA), grant M3.1.2/F/050/2011. CITA-A is also fully acknowledged. The project has been also funded by the INIA and European Regional Development Fund $n^{\circ}$ RZ2004-00009. We thank the veterinarians of the UCTL and all the breeders who provided the blood samples. We also thank Ms. Meredith Cannella for her English correction and documentation of the manuscript, and R. Parellada, E. Martín, and E. Solano for technical assistance during this work.

\section{References}

ARCTTC - Associação Regional de Criadores de Toiros da Tourada à Corda. 2006. Breeders. Bull Breeders Association of Azorean Street Bullfighting [on line]. Available at: $<$ http://www.toiroscorda.com $>$. Accessed on: Oct. 4, 2010.

Bandelt, H. J.; Forster, P. and Röhl, A. 1999. Median-joining networks for inferring intraspecific phylogenies. Molecular Biology and Evolution 16:37-48

BOE - Boletín Oficial del Estado. 2001. Royal decree 60/2001, of 26 January Lidia bovine breed phenotypic prototype. Official State Newsletter 38:5255-5261.

Bradley, D. G.; MacHugh, D. E.; Cunningham, P. and Loftus, R. T. 1996. Mitochondrial diversity and the origins of African and European cattle. Proceedings of the National Academy of Sciences of the United States of America 93:5131-5135.

Bruges, J. 1915. Terceira Island. Notes of Agriculture, Livestock and Industry. 1st ed. Scholl of Agronomy - University of Lisbon, Lisbon.

Carvajal-Carmona, L. G.; Bermudez, N.; Olivera-Angel, M.; Estrada, L.; Ossa, J.; Bedoya, G. and Ruiz-Linares, A. 2003. Abundant mtDNA diversity and ancestral admixture in Colombian criollo cattle (Bos taurus). Genetics 165:1457-1463.

Cortés, O.; Sevane, N.; Baro, J. A. and Cañón, J. 2014. Pedigree analysis of fragmented population, the Lidia cattle breed. Livestock Science 167:1-8.

Cortés, O.; Tupac-Vupanqui, I.; Dunner, S.; Fernández, J. and Cañón, J. 2011. Y chromosome genetic diversity in the Lidia bovine breed: a highly fragmented population. Journal of Animal Breeding and Genetics 128:491-496.

Cortés, O.; Tupac-Yupanqui, I.; Dunner, S.; García-Atance, M. A.; García, D.; Fernández, J. and Cañón, J. 2008. Ancestral matrilineages and mitochondrial DNA diversity of the Lidia cattle breed. Animal Genetics 39:649-654.

Correia, P.; Baron, E. and Moreira da Silva, F. 2015. Selection traits of lidia cattle for Azorean street bullfighting. Archivos de Zootecnia 64:13-20.

Correia, P.; Baron, E.; da Silva, J. M. and Cortés, O. 2014. Genetic relationships of the Portuguese Lidia bovine populations. Iranian Journal of Veterinary Research 15:364-369.

Department of Azorean Agriculture and Foresty. 2010. Official Azorean Government Newsletter n ${ }^{\circ} 45 / 2010$, 6th May.

Excoffier, L.; Laval, G. and Schneider, S. 2005. ARLEQUIN version 3.0: an integrated software package for population genetics data analysis. Evolutionary Bioinformatics Online 1:47-50.

Ginja, C.; Penedo, M. C.; Melucci, L.; Quiroz, J.; Martinez Lopez, O. R.; Revidatti, M. A.; Martinez-Martinez, A.; Delgado, J. V. and 
Gama, L. T. 2010. Origins and genetic diversity of New World Creole cattle: inferences from mitochondrial and Y chromosome polymorphisms. Animal Genetics 41:128-141.

Kumar, S.; Tamura, K.; Jakobsen, I. B. and Nei, M. 2001. MEGA2: molecular evolutionary genetics analysis software. Bioinformatics 17:1244-1245.

Loftus, R. T.; MacHugh, D. E.; Bradley, D. G.; Sharp, P. M. and Cunningham, P. 1994. Evidence for two independent domestications of cattle. Proceedings of the National Academy of Sciences of the United States of America 91:2757-2761.

López del Ramo, J. 2002. Las claves del toro. 1st ed. Espassa Calpe, Madrid.

Lucas, V. 2006. Portuguese bullfighting breeders 2006. 1st ed. Association of Portuguese Lidia Cattle Breeders, Porto Alto.

Mateus, J. C. and Russo-Almeida, P. A. 2014. Exploring the genetic diversity and substructure of the Portuguese cattle breed "Brava de Lide" using microsatellites. Animal Genetic Resources 55:9-17.

Neves, F. P. B. 1992. O toiro de lide em Portugal. 1st ed. INAPA, Lisbon.
Pelayo, R.; Valera, M.; Molina, A. and Royo, L. J. 2015. Contribution of Lidia cattle breed historical castes to the paternal genetic stock of Spain. Animal Genetics 46:312-315.

Sambrook, J.; Fritsch, E. F. and Maniatis, T. 1989. Molecular cloning: A laboratory manual. 2nd ed. Cold Spring Harbor Laboratory Press, Cold Spring Harbor, New York.

Silva, B.; Gonzalo, A. and Cañón, J. 2006. Genetic parameters of aggressiveness, ferocity and mobility in the fighting bull breed. Animal Research 55:65-70.

Silva, I. 2011. Ganadaria da ilha Terceira. Casa Agrícola José Albino Fernandes. 1st ed. BLU Editions, Angra do Heroísmo.

UCTL - Unión de Criadores de Toros de Lidia. 2011. Unión de Criadores de Toros de Lidia - Temporada 2011. 1st ed. Unión de Criadores de Toros de Lidia, Madrid.

Troy, C. S.; Machugh, D. E.; Bailey, J. F.; Magee, D. A.; Loftus, R. T.; Cunningham, P.; Chamberlain, A. T.; Sykes, B. C. and Bradley, D. G. 2001. Genetic evidence for Near-Eastern origins of European cattle. Nature 410:1088-1091. 